\title{
Фотоприемные устройства на основе наноразмерных гетероструктур InAs/GaSb
}

\author{
Л.В. Данилов, Р.В. Левин, И.В. Федоров, Н.В. Павлов, В.Н. Неведомский, Б.В. Пушный, \\ М.П. Михайлова, И.А. Андреев, Г.Г. Зегря \\ Физико-технический институт им. А.Ф.Иоффе, Санкт-Петербург, \\ 194021, Политехническая, 26 \\ тел:+7 (812) 292-7367, факс:+7 (812) 292-7367, эл.nочта: danleon84@mail.ioffe.ru
}

DOI 10.34077/RCSP2019-159

Фотоприемные устройства (ФПУ) ближнего и среднего инфракрасного диапазона находят применение в самых различных областях науки и техники. Прежде всего, это - оптические телекоммункационные системы (ВОЛС, АОЛС), системы дальнометрии и целеуказания, комплексы экологического мониторинга и тепловизуализации. Разработка и создание таких устройств является одной приоритетных задач ИК оптоэлектроники.

В настоящее время много внимания уделяется созданию ФПУ на основе системы объемных материалов $\mathrm{HgCdTe} / \mathrm{CdTe}$. Сравнительно простой способ управления областью поглощения за счет изменения состава тройного раствора $\mathrm{HgCdTe}$ позволяет создавать широкополосные ФПУ для среднего и дальнего ИК диапазона на основе варизонных гетероструктур [1]. Однако, спектральная чувствительность таких устройств невелика из-за высокой вероятности безызлучательной Ожерекомбинации и межзонного туннелирования. Эти факторы значительно сокращают время жизни фотовозбужденных носителей заряда, что особенно характерно для высоких рабочих температур $(\mathrm{T}>100 \mathrm{~K})$.

Принципиально другим подходом к созданию ФПУ для ближнего, среднего и дальнего ИКдиапазона является разработка устройств $\mathrm{c}$ активной областью на основе напряженных наноразмерных гетероструктур II типа InAs/GaSb. Преимуществом подобных гетероструктур является значительное подавление процессов безызлучательной Оже-рекомбинации и межзонного туннелирования за счет разделения областей пространственной локализации электронов и дырок [2]. В настоящей работе сообщается о разработке ФПУ на основе сверхрешеток InAs/GaSb, а также гетероструктур с единичной квантовой ямой $\mathrm{n}-\mathrm{GaSb} / \mathrm{InAs} / \mathrm{p}-\mathrm{GaSb}$. В рамках технологии газофазной эпитаксии из металлорганических соединений (МОСГФЭ) были синтезированы чередующиеся слои InAs и GaSb c толщинами от 1 до 3 нм, при этом толщина переходных слоев при скорости роста 1.5 нм/мин не превышала 0.5 нм. При исследовании фото и электролюминесценции полученных образцов наблюдались интенсивные спектры излучения в диапазоне длин волн 2200-4600 нм, что хорошо согласуется с теоретическим расчетом энергетического спектра рассматриваемых гетероструктур. При исследовании фотоэлектрических свойств диодной гетероструктуры с единичной квантовой ямой $\mathrm{n}-\mathrm{GaSb} / \mathrm{InAs} / \mathrm{p}-\mathrm{GaSb}$ наблюдался эффект увеличения дифференциальной фотопроводимости при малых обратных смещениях (менее $200 \mathrm{mB}$ ) по сравнению с объемной $\mathrm{p}-\mathrm{i}-\mathrm{n}$ структурой на основе $\mathrm{GaSb}[3,4]$. Данный эффект наблюдался при фотовозбуждении монохроматическим излучением с длиной волны 1.55 мкм. Значение ватт-амперной чувствительности при этом достигало величины $4.2 \cdot 10^{2} \mathrm{~A} / \mathrm{B}$. Принимая во внимание, что высокий уровень спектральной чувствительности достигается при малых внешних смещениях, обнаруженный эффект можно рассматривать как основу для создания компактных фотоприемников для высокоскоростных коммуникационных систем с низким энергопотреблением.

\section{Лumepamypa}

[1] Piotrowski et al., Infrared Physics \& Technology 49, 173, (2007).

[2] G.G. Zegrya et al., Appl. Phys. Lett. 67, 2681, (1995).

[3] L.V. Danilov et al., Semiconductors, v.51 (9), pp. 1148-1152, (2017).

[4] M.P. Mikhailova et al., Semiconductors, v.52 (8), pp. 1037-1042, (2018). 